\title{
Studies on Influence of Admixtures and Aggregate Curing Conditions on the Strength of Lightweight Expanded Clay Aggregate Concrete
}

\author{
Goggi Abhishek ${ }^{1}$, Tangudu Manoj ${ }^{2}$ and Dr. M. V. Seshagiri Rao ${ }^{3}$ \\ ${ }^{1}$ M. Tech. Student/CVR College of Engineering /Civil Engineering Department, Hyderabad, India \\ Email: goggiabhishek@gmail.com \\ ${ }^{2}$ Asst. Professor/CVR College of Engineering /Civil Engineering Department, Hyderabad, India \\ Email: manoj.tangudu03@gmail.com \\ ${ }^{3}$ Professor/CVR College of Engineering /Civil Engineering Department, Hyderabad, India \\ Email: rao_vs_meduri@yahoo.com
}

\begin{abstract}
Lightweight concrete can be produced by replacing the normal aggregate with lightweight aggregate either partially or fully, depending upon the requirements of density and strength. The present study covers the influence of different aggregate curing conditions and admixtures on the strength of lightweight expanded clay aggregate concrete under normal curing and vacuum curing with and without addition of silica fume. The grade of the concrete is M40. The lightweight aggregate used is LECA, an expanded clay aggregate. Investigations were carried out up to a replacement of $50 \%$ of coarse aggregate. The workability and strength at different ages are presented.
\end{abstract}

Index Terms: Lightweight Expanded Clay Aggregate (LECA), Admixtures, Density, workability, Compressive strength

\section{INTRODUCTION}

Concrete is one of the most widely used construction material in modern constructions and infrastructure needs. It is used as a construction material because it can be moulded into any structural form and shape. The density of normal concrete ranges from 2200 to $2600 \mathrm{Kg} / \mathrm{m}^{3}$, self-weight occupies a very large load coming on the structures critically in cases such as weak soils and tall structures.

Lightweight concrete plays a major role in reducing the density of the concrete. It is used worldwide in many construction projects where soil is weak and heavy constructions are to be done, Lightweight concrete density varies from 300 to $1800 \mathrm{Kg} / \mathrm{m}^{3}$. LWC can be produced by using lightweight materials like Lightweight Expanded Clay Aggregate, Pumice stone, expanded shale, Perlite etc.

Structural lightweight aggregate can be produced naturally or from environmental waste. Use of these aggregates can reduce the density of concrete, the selfweight of the structure and it helps to construct larger precast unit.

The main objective of the present experimental study is to investigate the properties of lightweight expanded clay aggregate concrete (LECAC) under normal curing conditions and vacuum curing.

\section{LITERATURE REVIEW}

R.N.Rajprakash, A.Krishnamoorthi [1] studied the effect of partial replacement of coarse aggregate (Jelly) in concrete by Light weight coarse aggregate (LECA). They have partially replaced natural aggregates by using LECA by $20 \%, 40 \%, 60 \%, 80 \%$ and $100 \%$. Compressive strength of $29.85 \mathrm{~N} / \mathrm{mm}^{2}$ at $20 \%$ LECA replacement for a water curing for a period of 28 days.

M.MAHDY [4] investigated the Mechanical properties, workability of lightweight concrete using LECA as lightweight aggregate. High strength concrete is achieved by treating LECA with Silica fume solution of different concentrations $(10 \% \& 20 \%)$ by weight of mixing water. Three silica fume levels of different percentage's $(5,10$, and $15 \%)$ and two coarse to total aggregate content $(0.48,0.65)$ by volume were used. Results showed that use of cured LECA increased the compressive strength and flexural strength.

N.Sellakkannu and C.Tamilarasan [6] examined the properties of concrete which were determined by tests conducted on concrete such as Concrete Density, Porosity, Ultrasonic pulse velocity and Compressive \& Split tensile strength. The test results and examination of the concrete samples using Optical Microscope shows that there is a strong bonding between the cement paste and LECA.

Serkan Subasi [12] studied the effect of fly ash in High strength light weight aggregate concrete produced with LECA. The Physical and Mechanical properties of the concrete were investigated. Concrete mixes with 350,400 and $450 \mathrm{~kg} / \mathrm{m}^{3}$ cement content and with $0 \%, 10 \%, 20 \%$ and $30 \%$ flyash as replacement of cement content were casted.

They found that Physical and Mechanical properties are enhanced by adding mineral admixtures, Ultrasonic pulse velocity is increased by $3 \%$, Compressive strength is increased by $8 \%$; and Split tensile strength is increased by $9 \%$ for the concretes with various cement contents. 


\section{EXPERIMENTAL STUDY}

\section{A. Materials}

This section gives the details of the characteristics of the different materials used in this experimental study.

\section{Cement}

Cement is used as a binding material. In this experimental study Ordinary Portland Cement of Grade 53 is used. The cement is found to be conforming to various specifications of IS 12269-1987.The physical properties of cement are tested and the results are tabulated in the Table I as per IS 4031-1998.

TABLE I.

PHYSICAL PROPERTIES OF CEMENT

\begin{tabular}{|c|c|}
\hline Test & Result \\
\hline Specific gravity & 3.10 \\
\hline Standard consistency & $34 \%$ \\
\hline Initial setting time & 45 minutes \\
\hline Final setting time & 489 minutes \\
\hline Bulk density & $1440 \mathrm{~kg} / \mathrm{m}^{3}$ \\
\hline Fineness of cement & $2.4 \%$ \\
\hline
\end{tabular}

\section{Aggregates}

Aggregates are the inert granular materials such as sand, gravel, or crushed stone that are mixed along with water and Portland cement to make concrete. They are essential ingredients in making concrete.

\section{Coarse aggregate (Gravel)}

In present experimental work coarse aggregate passing through $12 \mathrm{~mm}$ IS sieve and retaining on $10 \mathrm{~mm}$ IS sieve is used. Certain care is taken while choosing coarse aggregate and it is seen that it is free from impurities. Characteristic Tests are conducted to find out the properties of the coarse aggregate and are tabulated in the Table II.

\section{Coarse aggregate (LECA)}

Lightweight expanded clay aggregate (LECA) is used as the lightweight aggregate which is of size 8 to $12 \mathrm{~mm}$. LECA is free from impurities. Characteristic tests are also performed on LECA and the results are tabulated in Table II.
TABLE II.

PHYSICAL PROPERTIES OF COARSE AGGREGATE

\begin{tabular}{|c|c|c|}
\hline Property & Coarse aggregate & LECA \\
\hline Fineness modulus & 6.41 & 5.84 \\
\hline Specific gravity & 2.43 & 0.71 \\
\hline Bulk density & $1420 \mathrm{~kg} / \mathrm{m}^{3}$ & $410 \mathrm{~kg} / \mathrm{m}^{3}$ \\
\hline Water absorption & $0.6 \%$ & $30 \%$ \\
\hline
\end{tabular}

Fine aggregate

Fine aggregate used in this experimental work is locally available river sand, care is taken to see that the sand is free from impurities, waste stones and to remain clean. Sand used is confirming to the requirements of IS: 383-1970. Characteristic tests are conducted on fine aggregate and the properties of fine aggregate are tabulated in Table III.

TABLE III.

PHYSICAL PROPERTIES OF FINE AGGREGATE

\begin{tabular}{|c|c|}
\hline Test & Result \\
\hline Fineness modulus & 3.085 \\
\hline Specific gravity & 2.59 \\
\hline Bulk density & $1570 \mathrm{~kg} / \mathrm{m}^{3}$ \\
\hline Water absorption & $1 \%$ \\
\hline
\end{tabular}

\section{Mineral Admixture}

Micro silica, as a replacement to the cement, is used as the mineral admixture in order to improve the strength of the lightweight concrete and also to avoid segregation of concrete.

\section{Chemical Admixture}

Admixtures, natural or manufactured chemicals, are added to the concrete before or during concrete mix. Admixtures are used in the tests have the qualities of airentraining, water reducers, water reducing accelerators or retarders. Use of admixture will improve the workability of the concrete strength.

In the present study, CONPLAST SP 430 is used. It is used to improve the workability of the concrete and also specially formulated to give high water reductions upto $25 \%$ without loss of workability and also reduce permeability to give high quality concrete.

\section{Water}

Water is the most important ingredient of concrete which helps to bind the cement content and aggregates. Clean potable water is used for concrete mixes.

\section{B. Mix Design}

In the present study, the mix design of the Lightweight expanded clay aggregate concrete (LECAC) was done using the code IS:10262-2009 and IS:456-2000. In the coarse aggregate content of the mix, $50 \%$ of the normal aggregate is replaced with LECA to obtain lightweight concrete in the present studies. The chemical admixture i.e. SP 430 is used in order to improve workability and mineral admixture 
(Micro silica) is added in addition to cement in strength development of LECAC.

\section{Vacuum curing of Coarse aggregate (LECA)}

The amount of water absorbed by LECA while curing is less as it floats in the water. In order to improve the water absorption and fill the air voids, LECA is placed in the vacuum chamber and the moisture is removed by passing vacuum through the clay aggregate. This vacuum curing is done for 24 hours and the air voids present in the clay aggregate is filled with the water which results in the increase in the water absorption there by increasing the compressive strength of the LECA concrete.

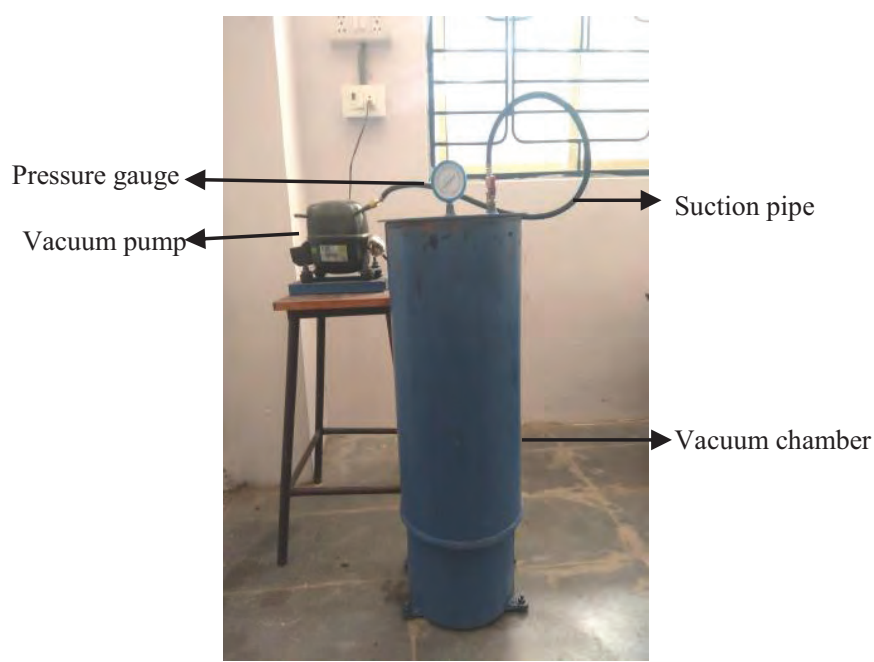

Figure 2. Vacuum curing chamber

Casting of specimen

The fresh concrete was casted using different watercement ratio i.e. $0.35,0.40,0.45$ and different super plasticizer dosage for each $\mathrm{w} / \mathrm{c}$ ratio. For each mixture, cube cylinder and prism specimens of size 150x150x150mm, 150x300mm and 100x100x500mm were casted respectively. The composition of LWC mixtures are represented in Table IV.
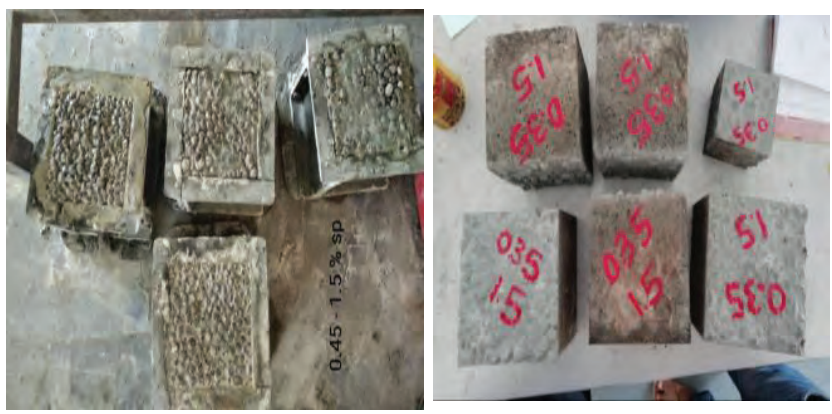

Figure 3. Casting of cube specimens

\section{Curing of specimens}

All the casted concrete specimens were cured by placing the specimens in the curing tank containing water for a period of 28 days. The LECA was also cured using vacuum curing method by placing it in a vacuum chamber for 24 hours and then used in casting of LWC.

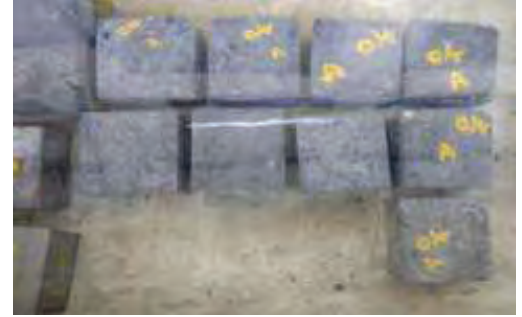

Figure 4. Curing of cube specimens

TABLE IV.

COMPOSITION OF LIGHTWEIGHT EXPANDED CLAY AGGREGATE CONCRETE MIXTURES

\begin{tabular}{|c|c|c|c|c|c|c|c|}
\hline $\begin{array}{c}\text { Mix } \\
\text { No. }\end{array}$ & $\begin{array}{c}\text { W/C } \\
\text { ratio }\end{array}$ & $\begin{array}{c}\text { Cement } \\
\left(\mathrm{Kg} / \mathrm{m}^{3}\right)\end{array}$ & $\begin{array}{c}\mathrm{MS} \\
\left(\mathrm{Kg} / \mathrm{m}^{3}\right)\end{array}$ & $\begin{array}{c}\text { Water } \\
\text { content } \\
\left(\mathrm{Kg} / \mathrm{m}^{3}\right)\end{array}$ & $\begin{array}{c}\text { C.A } \\
\left(\mathrm{Kg} / \mathrm{m}^{3}\right)\end{array}$ & $\begin{array}{c}\text { LECA } \\
\left(\mathrm{Kg} / \mathrm{m}^{3}\right)\end{array}$ & $\begin{array}{c}\text { F.A } \\
\left(\mathrm{Kg} / \mathrm{m}^{3}\right)\end{array}$ \\
\hline M1 & 0.35 & 450 & 0 & 157.5 & 534.60 & 156.20 & 614.01 \\
\hline M2 & 0.40 & 425 & 0 & 170 & 523.66 & 153.00 & 627.42 \\
\hline M3 & 0.45 & 400 & 0 & 180 & 513.94 & 150.16 & 642.99 \\
\hline M4 & 0.35 & 405 & 45 & 157.5 & 534.60 & 156.20 & 614.01 \\
\hline M5 & 0.40 & 382.5 & 42.5 & 170 & 523.66 & 153.00 & 627.42 \\
\hline M6 & 0.45 & 360 & 40 & 180 & 513.94 & 150.16 & 642.99 \\
\hline
\end{tabular}

\section{EXPERIMENTAL METHODOLOGY}

The casted concrete specimens are tested as per standard testing procedures. The Experimental Results of the Lightweight expanded clay aggregate concrete such as Workability, Unit weight, water absorption of LECA, compressive strength, split tensile strength, Flexural strength of the LECA Concrete (LECAC50) is represented in this section.

\section{A. Water absorption of LECA}

The water absorption of LECA aggregate is found out by using water curing, vacuum curing. The results are given in table $\mathrm{V}$.

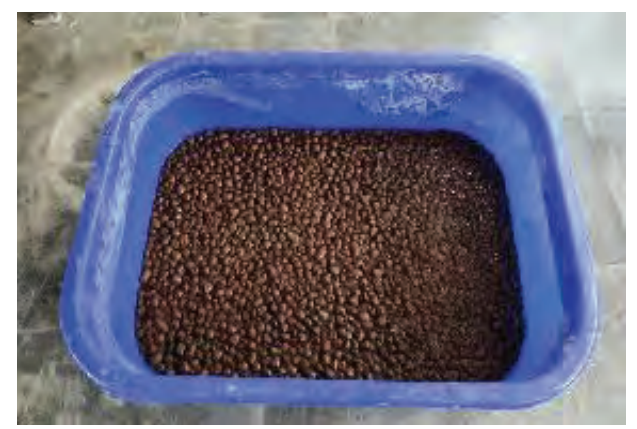

Figure 5. LECA Water absorption test

\section{B. Workability}

The workability of the LECAC50 is measured by conducting the Slump cone test using standard Procedure prescribed in IS: 1199 - 1959 and given in Table VI. 

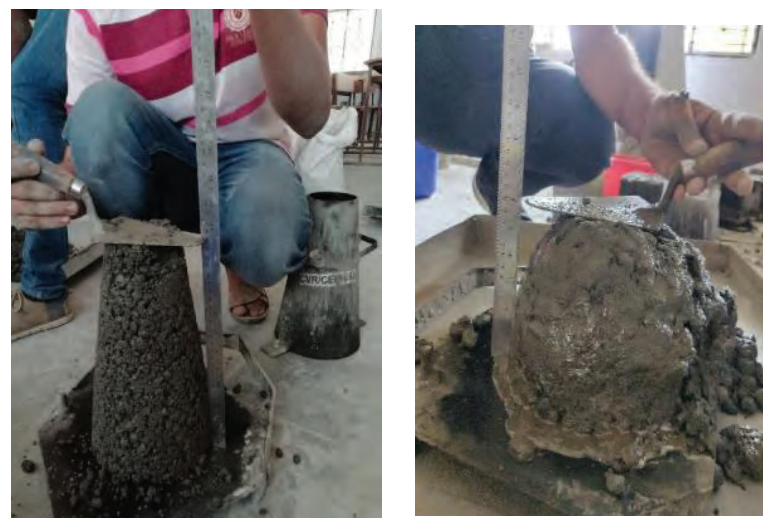

Figure 6. Workability test of LECAC50 using Slump cone test

\section{Compressive Strength}

Cubes of size $150 \times 150 \times 150 \mathrm{~mm}$ were casted and allowed for curing in curing tank for 28 days and 56 days. And tested in Automatic compression testing machine of $2000 \mathrm{KN}$ capacity.
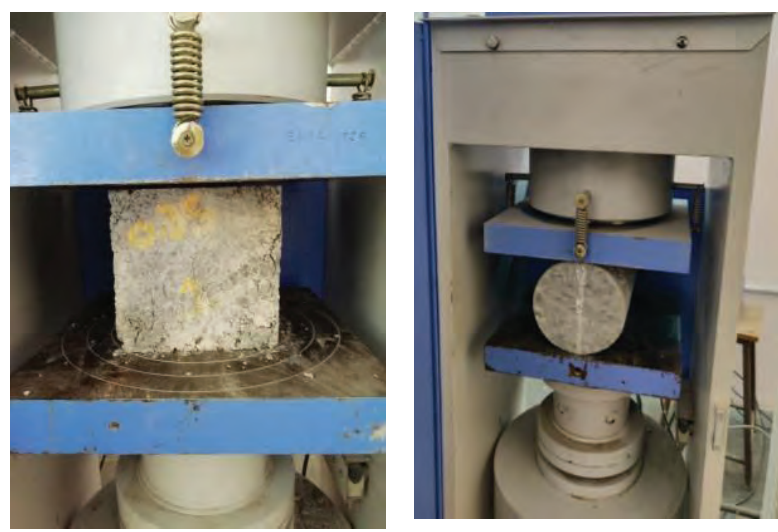

Figure 7. Compressive strength test and Split tensile test of LECAC50 cube and cylindrical specimen respectively with Automatic compression testing machine of $2000 \mathrm{kN}$ capacity

\section{Flexural strength}

Prisms of size $100 \times 100 \times 500 \mathrm{~mm}$ were casted and allowed for curing in curing tank for a period of 28 days and tested in flexural testing machine.
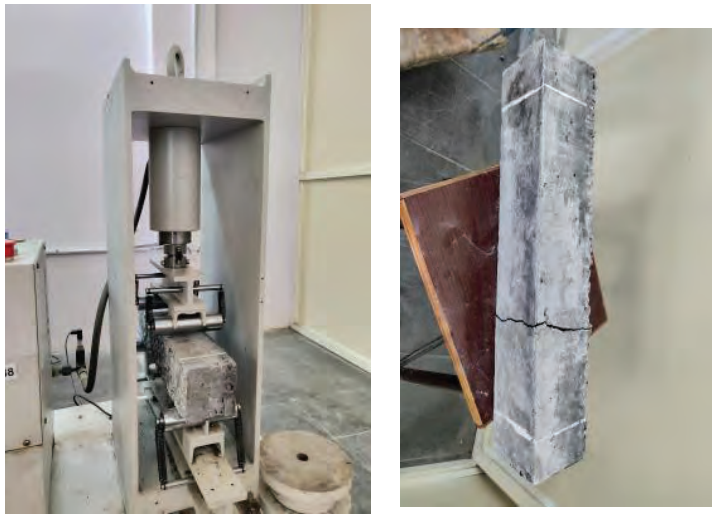

Figure 8. Flexural strength of LECAC50 prism along its failure

\section{E. Split tensile strength}

Cylinders of size $150 \times 300 \mathrm{~mm}$ were casted and allowed for curing in curing tank for 28 days and tested in the
Automatic compression testing machine of $2000 \mathrm{KN}$ capacity.

\section{EXPERIMENTAL RESULTS}

TABLE V.

COMPARISION OF WATER ABSORPTION OF LECA

\begin{tabular}{|c|c|c|c|}
\hline Property & $\begin{array}{c}\text { Normal } \\
\text { LECA }\end{array}$ & $\begin{array}{c}\text { Partially saturated } \\
\text { surface dried LECA }\end{array}$ & $\begin{array}{c}\text { Vacuum cured } \\
\text { LECA }\end{array}$ \\
\hline $\begin{array}{c}\text { Water } \\
\text { absorption }\end{array}$ & $0.85 \%$ & $14 \%$ & $75 \%$ \\
\hline
\end{tabular}

TABLE VI.

WORKABILITY OF LECAC50

\begin{tabular}{|c|c|c|}
\hline Trial Mix No. & W/C ratio & Slump(mm) \\
\hline \multirow{3}{*}{$\begin{array}{c}\text { Partially Saturated Surface } \\
\text { Dried LECA }\end{array}$} & M1 & 60 \\
\cline { 2 - 3 } & M2 & 63 \\
\hline \multirow{2}{*}{$\begin{array}{c}\text { Partially Saturated Surface } \\
\text { Dried LECA with Micro Silica }\end{array}$} & M3 & 78 \\
\cline { 2 - 3 } & M4 & 48 \\
\hline \multirow{3}{*}{\begin{tabular}{c} 
Vacuum Cured LECA \\
\cline { 2 - 3 }
\end{tabular}} & M6 & 52 \\
\cline { 2 - 3 } & M1 & 58 \\
\hline \multirow{2}{*}{$\begin{array}{c}\text { Vacuum cured LECA with } \\
\text { Micro Silica }\end{array}$} & M3 & 52 \\
\cline { 2 - 3 } & M5 & 69 \\
\cline { 2 - 3 } & M6 & 60 \\
\hline
\end{tabular}

The compressive strength of various proportions of LECAC50 for different curing periods such as 28 days and 56 days are analyzed. The results are tabulated in the Table VII. The split tensile and flexural strength results are tabulated in Table VIII, Table IX respectively.

TABLE VII.

COMPRESSIVE STRENGTH OF LECAC50

\begin{tabular}{|c|c|c|c|c|}
\hline \multirow{2}{*}{ LECA TYPE } & \multirow{2}{*}{ Mix } & \multicolumn{2}{|c|}{$\begin{array}{c}\text { Compressive strength } \\
\text { (MPa) }\end{array}$} & \multirow{2}{*}{$\begin{array}{l}\% \text { increase } \\
\text { in strength }\end{array}$} \\
\hline & & 28 Days & 56 Days & \\
\hline \multirow{3}{*}{$\begin{array}{l}\text { Partially Saturated } \\
\text { Surface Dried LECA }\end{array}$} & M1 & 33.40 & 35.82 & $5.13 \%$ \\
\hline & M2 & 29.59 & 31.09 & $5.06 \%$ \\
\hline & M3 & 27.30 & 28.54 & $4.54 \%$ \\
\hline \multirow{3}{*}{$\begin{array}{l}\text { Partially Saturated } \\
\text { Surface Dried LECA } \\
\text { with Micro Silica }\end{array}$} & M4 & 36.20 & 37.92 & $4.75 \%$ \\
\hline & M5 & 31.92 & 33.21 & $4.04 \%$ \\
\hline & M6 & 29.86 & 31.04 & $3.95 \%$ \\
\hline \multirow{3}{*}{ Vacuum Cured LECA } & M1 & 36.95 & 39.62 & $7.22 \%$ \\
\hline & M2 & 32.84 & 34.87 & $6.18 \%$ \\
\hline & M3 & 29.36 & 31.11 & $5.98 \%$ \\
\hline \multirow{3}{*}{$\begin{array}{l}\text { Vacuum cured LECA } \\
\text { with Micro Silica }\end{array}$} & M4 & 39.94 & 43.21 & $8.18 \%$ \\
\hline & M5 & 35.14 & 37.74 & $7.39 \%$ \\
\hline & M6 & 32.79 & 34.95 & $6.58 \%$ \\
\hline
\end{tabular}


TABLE VIII.

SPLIT TENSILE STRENGTH OF LECAC50

\begin{tabular}{|c|c|c|}
\hline \multirow{2}{*}{$\begin{array}{c}\text { Design Mix } \\
\text { No. }\end{array}$} & \multicolumn{2}{|c|}{ Split tensile strength (MPa) } \\
\cline { 2 - 3 } & With Microsilica & Without Microsilica \\
\hline M1 & 8.4 & 7.2 \\
\hline M2 & 8.7 & 7.7 \\
\hline M3 & 9.9 & 8.4 \\
\hline
\end{tabular}

TABLE IX

FLEXURAL STRENGTH OF LECAC50

\begin{tabular}{|c|c|c|}
\hline \multirow{2}{*}{ Design Mix No. } & \multicolumn{2}{|c|}{ Flexural strength (MPa) } \\
\cline { 2 - 3 } & With Microsilica & Without Microsilica \\
\hline M1 & 6.24 & 6.15 \\
\hline M2 & 6.20 & 6.02 \\
\hline M3 & 5.93 & 5.79 \\
\hline
\end{tabular}

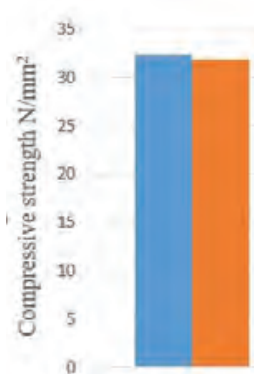

0.35

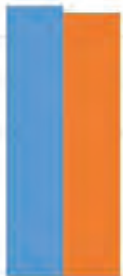

0.4 W/C Ratio

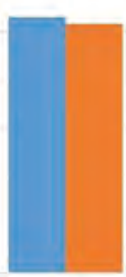

0.45 m LECACA0 - LECACSO

Figure 9. Comparison of compressive strength for LECAC40 and LECAC50 Mix at age of 28 days

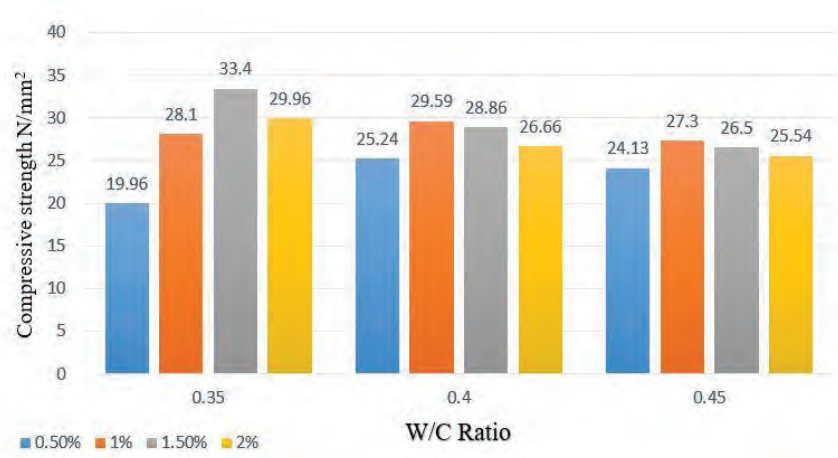

Figure 10. Compressive Strength of LECAC50 Trial Mixes for different $\mathrm{W} / \mathrm{C}$ ratio and chemical admixture dosage

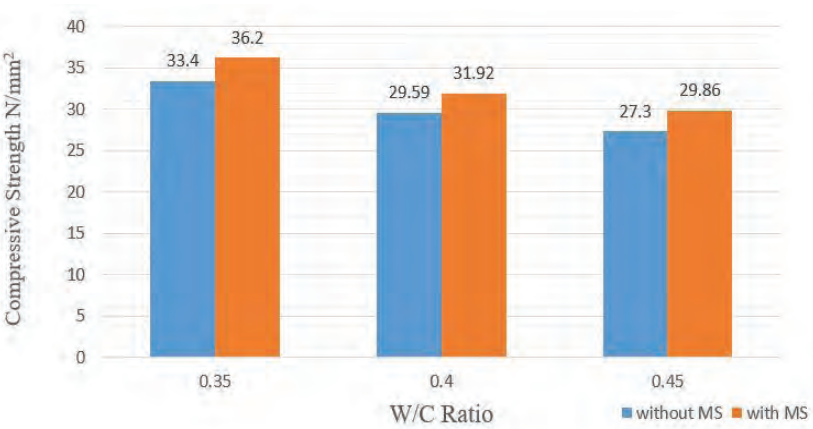

Figure 11. Variation of compressive strength of LECAC50 mix with Partially saturated surface dried LECA with and without addition of $10 \%$ Microsilica at age of 28 days

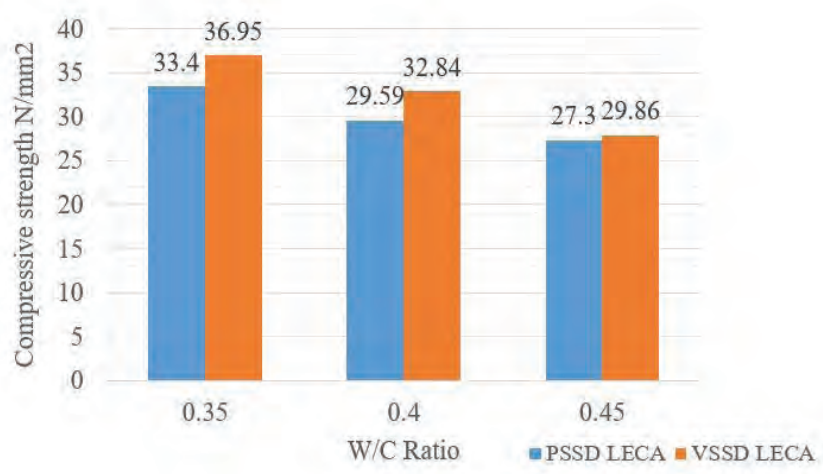

Figure 12. Variation of compressive strength of LECAC50 with Partially saturated surface dried LECA and vacuum cured LECA at age of 28 days

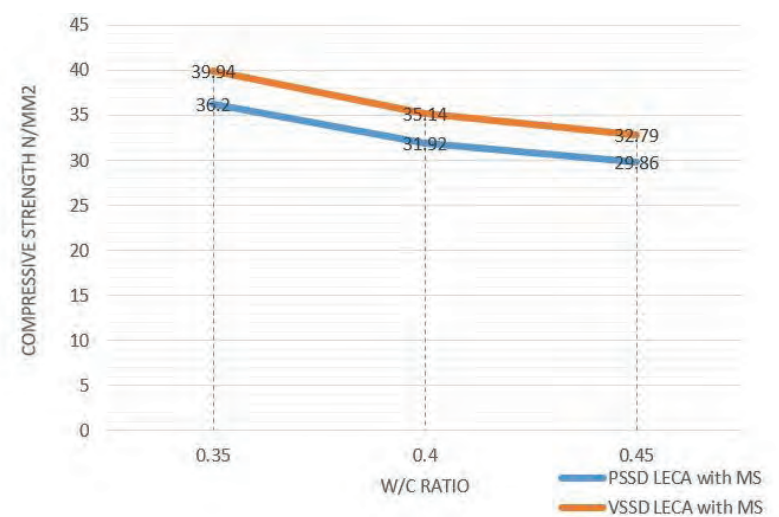

Figure 13. Variation of compressive strength development of LECAC50

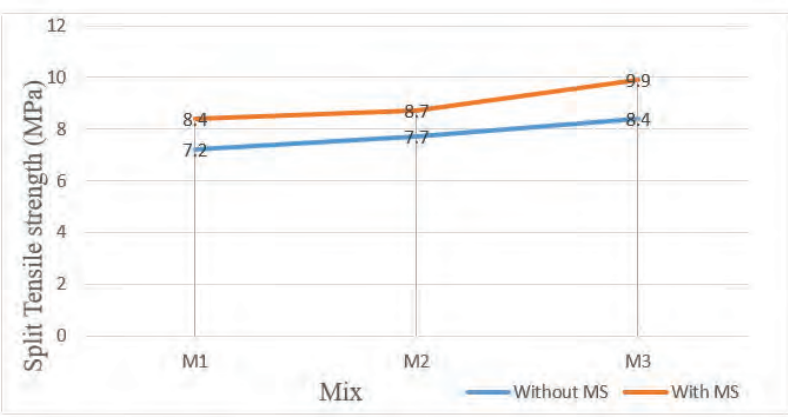

Figure 14. Variation of Split tensile strength of LECAC50

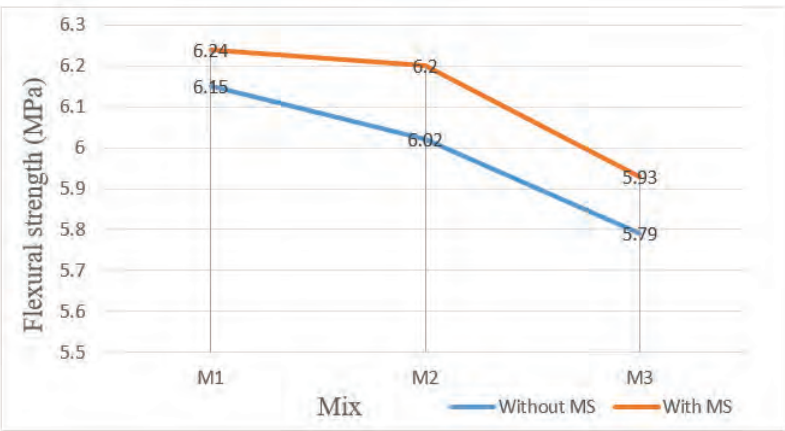

Figure 15. Variaiton of Flexural strength of LECAC50 


\section{CONCLUSIONS}

The following conclusions are drawn from the Experimental Investigation

- The unit weight of LECAC50 mix was found to be in the range of $1700 \mathrm{Kg} / \mathrm{m}^{3}$ to $1780 \mathrm{Kg} / \mathrm{m}^{3}$ which was less than the conventional concrete density.

- The addition of Conplast SP 430 to the LECAC50 improved its workability \& strength. The optimum dosage of chemical admixture obtained for watercement ratios $0.35,0.40$, and 0.45 are $1.5 \%, 1 \%$, and $1 \%$ respectively.

- The addition of conplast SP 430 exhibits increase in the compressive strength by $6.13 \%$ for LECAC 50 .

- The vacuum cured LECA has a water absorption of $75 \%$, whereas the water absorption of partially saturated surface dried LECA for 1 day is $15 \%$, which shows an increase in water absorption with vacuum curing.

- The compressive strength of LECAC50 with vacuum cured LECA increased by $9.83 \%$ compared to partially saturated surface dried LECA.

- The addition of $10 \%$ Microsilica to LECAC50 with partially saturated surface dried LECA improved the compressive strength by $8 \%$.

- The addition of $10 \%$ Microsilica to LECAC50 with vacuum cured LECA increased the compressive strength by $10.33 \%$.

- The addition of $10 \%$ Microsilica has shown improvement in Split tensile strength and flexural strength of LECAC50.

- The development of compressive strength of LECAC50 at age of 56 days with vacuum cured LECA is increased compared to the partially saturated surface dried LECA as Micro silica reacts with the water available in the pores of the vacuum cured LECA.

\section{REFERENCES}

[1] R.N. Rajprakash, A. Krishnamoorthi, "Experimental study on Lightweight concrete using LECA", International Journal of ChemTech Research, Vol. 10 No.8, 2017.

[2] Priyanga. R, Rajeswari. L.B, "Experimental Investigation on Mechanical Properties of Lightweight Concrete using LECA and Steel", SSRG, International Journal of Civil Engineering, April 2017.

[3] Sheetal Shetkar, G. N. Shete, "Experimental Study on Concrete with Pumice Stone and Leca Aggregate as a Partial Replacement of Coarse Aggregate", International Journal for Scientific Research and Development, volume 5, Issue 3, 2017.

[4] M.Mahdy, "Structural Lightweight concrete using Cured LECA", International Journal of Innovations in Engineering and Technology, VOLUME 5, ISSUE 9, MARCH 2016.

[5] T. Sonia, R. Subashini "Experimental investigations on Mechanical properties of Lightweight concrete using LECA", International Journal of Scientific Research, Vol 5, Issue 11, 2016.

[6] N. Sellakkannu and C. Tamilarasan, "Feasibility Study on Lightweight Aggregates in Concrete", International Journal for Scientific Research and Development, Volume3 Issue 12 2016.
[7] Abhijitsinh Parmar, Urvish Patel et al. "Fresh concrete properties of lightweight concrete using EPS and LECA as a replacement of normal aggregates", International Journal of Engineering Development and Research, Volume 4, Issue 1, 2016.

[8] B. Nagashree, Dr. S. Vijaya, "Experimental study on Lightweight concrete using LECA and cinder as coarse aggregates", International Journal of Engineering Reesearch and Technology, Volume 4, Issue 7, 2015.

[9] Hanamanth shebannavar et al. "comparative study of LECA as a complete replacement of coarse aggregate by ACI method with equivalent likeness of strength of is method", International Research Journal of Engineering and Technology, Volume 2, Issue 8, 2015.

[10] Anil Kumar R, P. Prakash "Mechanical Properties of Structural Light Weight Concrete by Blending Cinder and LECA", International Advanced Research Journal in Science, Engineering and Technology, Volume 2 Issue 10, 2015.

[11] Lenka Bodnarova et al. "Behavior of Lightweight expanded clay aggregate concrete exposed to high temperatures", International Journal of Civil and Environmental Engineering, Vol 8, 2014.

[12] Serkan Subasi "The Effects of Fly ash on High Strength Light Weight Concrete Produced with Expanded Clay Aggregate", Scientific Research and Essay, Volume 4 April 2009. 